\title{
Stability Analysis of A.C. Voltage Controls for Shinkansen Feeding System with Multiple Power Converters
}

\author{
Ken Kunomura Member (Central Japan Railway Company) \\ Takafumi Koseki Member (The University of Tokyo)
}

Keywords: Tokaido Shinkansen, power converters, A.C. voltage control, EMTP, linearized circuit model, pole assignment

The recent introduction of very fast and frequent train services at Tokaido-Shinkansen makes it difficult to stabilize the feeding voltage only by compensating reactive power. The electronic frequency converter (EFC), which can achieve fast and continuous power control, used at Numazu frequency conversion substation, is expected to improve the stabilization of the feeding voltage effectively; this is because fixed power factor control strategy is adopted here.

Active power injection can be applied to change the feeding voltage more effectively than by the conventional reactive power compensation. However, it is very difficult to determine the appropriate values of the compensating active and reactive power. Therefore, a novel method is required for judging the stability of such power feeding systems, including power converters. The authors propose an appropriate stability judging method that is based on a simplified linearized circuit model whose circuit constants are empirically decided.

A numerical solution of the dynamic nonlinear circuit equation, for example, an electro magnetic transient program (EMTP), provides direct information about the stability of a control. However, the repetition of the complicated numerical simulation is timeconsuming, and the stability of the control strategy cannot be theoretically guaranteed. Another method for validating the stability of control strategies is required for straightforward discussion of the designs of converter controls. The results of the validation analysis should provide information on stability margins. Therefore, the authors have considered the linear approximation of the circuit states by using the mathematical framework for linear systems, i.e., the state space model, for modeling the feeding system along with the power converters that control the feeding voltage.

For simplicity, the transfer characteristic of the response of the feeding voltage to the output power converter has been approximated by a second order delay system, as shown in Fig. 1. The linearized simplified circuit model of the feeding power system, including two power converters, is shown in Fig. 2.

The authors have computed the pole assignment of the feeding system by using the approximate linear state equations. An example of the calculated results of the pole assignment of the feeding system is shown in Fig. 3. " $K p$ " is the proportional gain of the A.C. voltage controller of the power converter.

The authors have derived a linearized state space model of the feeding system for Tokaido-Shinkansen; this model also includes the power converters used for active power compensation for stabilizing the feeding voltage. Furthermore, the authors have computed the pole assignment of the feeding system on the basis of the linear approximation. One can judge the stability of the voltage control of converters and determine the stability margins by using the pole assignment. The authors have applied this stability judging method to the EFC at Numazu frequency conversion substation.

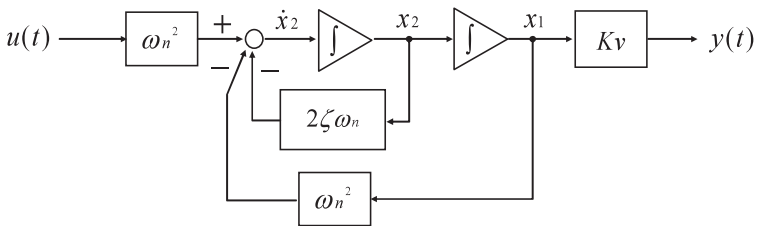

Fig. 1. The linearized circuit model of the feeding voltage response

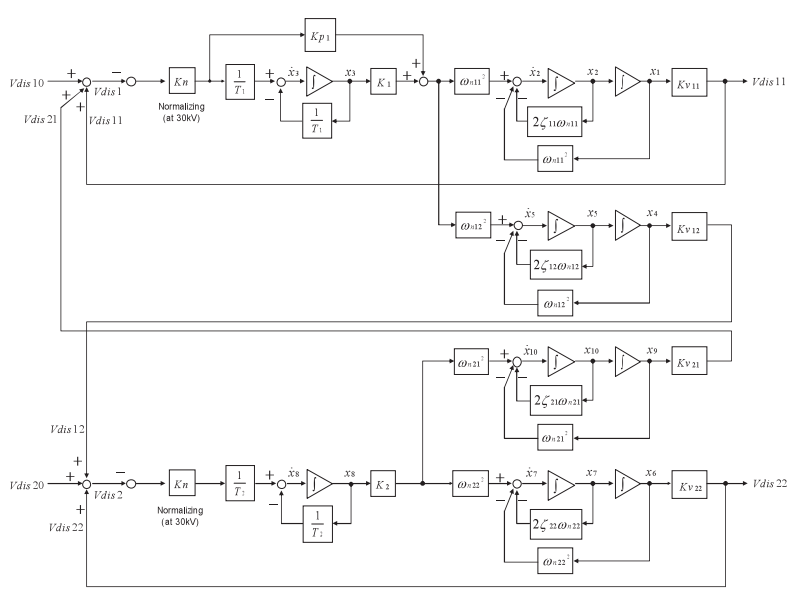

Fig. 2. The linearized circuit model of the feeding system with two power converters

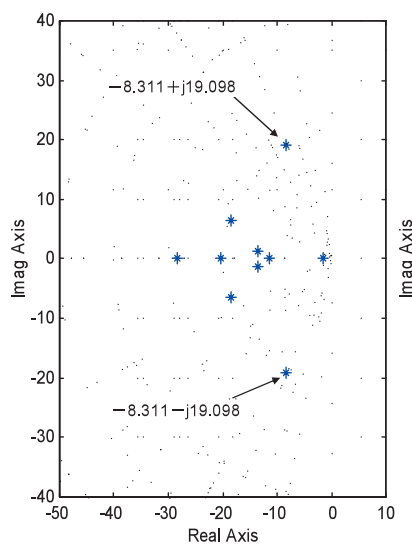

(a) $K p=2$

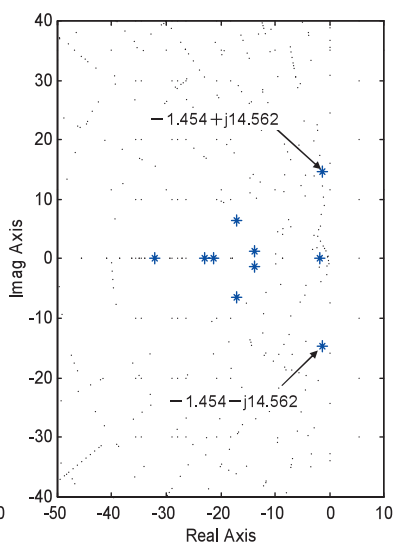

(b) $K p=0$
Fig. 3. The calculated pole assignment of the feeding system 


\title{
複数の電力変換装置を用いた新幹線き電システムの 交流電圧制御の安定性解析
}

\author{
正員 久野村 健* 正 員 古関 隆章** \\ Stability Analysis of A.C. Voltage Controls for Shinkansen Feeding System \\ with Multiple Power Converters
}

Ken Kunomura*, Member, Takafumi Koseki**, Member

\begin{abstract}
The recent introduction of very fast and frequent train services at Tokaido-Shinkansen makes it difficult to stabilize the feeding voltage only by compensating reactive power. Therefore, active power compensation has been introduced for further stabilization of the voltage, and a converter control strategy called "fixed power factor method" was applied in the commercial operation that started in February 2009. The feeding voltage stabilizing control by active power compensation is substantially more complicated than the conventional reactive power compensation. This paper describes a novel stability judging method for Shinkansen feeding system with multiple power converters; this method can be used to determine appropriate active/reactive compensation strategies that can be used by the operator of the new Shinkansen power supply system.
\end{abstract}

キーワード：東海道新幹線，電力変換装置，交流電圧制御， EMTP，線形回路モデル，極配置

Keywords: Tokaido Shinkansen, power converters, A.C. voltage control, EMTP, linearized circuit model, pole assignment

\section{1. はじめに}

東海道新幹線では，ダイヤの高密度化や車両の加速性能 の向上により，短時間で見た場合の有効電力は増加する傾 向にあり，この有効電力に起因する電圧変動は増大する傾向 にある。電源インピーダンスの大きいき電回路においては, 無効電力補償だけでは列車への電力の安定供給が困難とな る場合も想定されるようになった。このため, 有効電力供 給も行うことのできる，固定力率出力方式の電圧制御を行 う静止形周波数変換装置が開発され，実用化されている ${ }^{(1)}$ 。 有効電力供給を行う電力变換装置はき電電圧維持の面で の効果が大きく, その出力の変化に対するき電電圧変化が 大きい。つまり, 交流電圧制御に有効電力供給も用いる場 合, 電力変換装置の電圧制御の感度が大きくなりやすく, 電圧の安定制御が従来の無効電力供給による交流電圧制御 よりも難しいということがいえる。したがって，電源イン ピーダンスの大きいき電回路において電力変換装置により

\footnotetext{
* 東海旅客鉄道 (株)

干 108-8204 東京都港区港南 2-1-85

Central Japan Railway Company

2-1-85, Konan, Minato-ku, Tokyo 108-8204

** 東京大学大学院工学系研究科

干113-8656 東京都文京区本郷 7-3-1

The University of Tokyo

7-3-1, Hongo, Bunkyo-ku, Tokyo 113-8656
}

交流電圧制御を行う場合は, 交流電圧制御の安定性を見極 めたうえで, 体系的に電力変換装置の制御器設計を行うこ とが必要となってくる。

き電システムの過渡応答を計算する方法として瞬時值解 析シミュレーションソフトウェアである EMTP (Electro Magnetic Transient Program) による計算がよく用いられて おり, 実際のき電システムの過渡現象ともよく一致するこ とが知られている(2)。しかし, 複雑なき電システムの解析 を行う場合, EMTPによる計算では計算時間が膨大となり, 複数の制御方法や各種制御定数の組み合わせを EMTP で計 算して電力变換装置の制御器設計の評価を行うことは, 計 算時間の面で現実的でない。交流電圧制御の安定性が問題 となる電力変換装置の制御器設計を行うためには, システ ムの極配置を確かめながら制御器の設計を行うことが必要 であり, EMTP を用いた計算ではそれができない。極とは， 閉ループシステムの伝達関数の分母多項式の根であり, 極 が虚軸より右にあるとシステムが不安定となることが知ら れている。

また, 電力系統網の安定性解析方法については, 電力系 統網を RLC 回路網として線形回路モデル化し, BODE 線 図を作図するなどの方法により安定性解析を行っている例 がある(3)。しかし，き電システムには定電力特性を示す列 車負荷があり, 電力系統網とは違った非線形性の強いシス テムであるため, システムを単純な RLC 回路網として線 
形モデル化できない課題がある。

このため, 交流電圧制御を行う複数の電力変換装置を含 んだき電システムを線形回路モデルで近似し，比較的短時 間で，また，き電システムの極配置を確認しながら交流電 圧制御の安定性解析を行う手法を確立したので，以下に述 ベていく。

\section{2. 新幹線き電システムの安定性解析の手順概要}

複数の電力変換装置を用いた新幹線き電システムの交流 電圧制御の安定性解析の手順の概要は以下のとおりである。

〈2・1〉き電システムのブロック線図化 体系的に, か つ, 比較的短時間でき電システムの安定性解析を行うために は，き電システムを線形回路モデルに近似する必要がある。 このための第 1 ステップとして，電力変換装置の連系点の 電圧に着目して, き電システム全体をブロック線図で表す。

〈2・2〉き電システムの線形回路モデル化 き電シス テムは定電力特性を示す列車負荷を含むため, 電力变換装 置の出力に対するき電電圧応答は非線形性を示すが，この 部分を線形近似する。このき電電圧応答部分の線形近似を き電システムのブロック線図に当てはめ，き電システム全 体を線形回路モデル化する。

$\langle\mathbf{2} \cdot \mathbf{3}\rangle$ き電システムの状態方程式と極の算出 き電 システムの線形回路モデルをもとに, 列車負荷に起因する 電力変換装置連系点におけるき電電圧の外乱を入力とし, 電力変換装置の連系点電圧を出力とするき電システムの状 態方程式及び出力方程式を算出する。また, 状態方程式の システム行列から, き電システムの極を算出し, き電シス テムの安定性を定量的に判別する。

\section{3. き電システムのブロック線図}

〈3・1〉き電システムのモデルケースの設定＼cjkstart本論文 におけるモデルケースとしてのき電システムの電力系統図 を図 1 に示す。図 1 のき電システムの電力系統の構成は東 海道新幹線における一般的なき電システムの構成であり, き電用変電所でスコット結線変圧器により三相電力を単相 電力に変換している。単相き電回路は上下線別に構成され ており，き電回路末端のき電区分所で上下線を常時接続状 態としている。電力変換装置はき電用変電所とき電区分所 の 2 箇所に設備されている例を想定し, 電力変換装置 1 及 び 2 は, それぞれの連系点のき電電圧の変動を一定範囲内 に抑制する目的で設置する, 無効電力出力を行う静止形無 効電力補償装置 (SVC) として設定する。なお, 提案する安 定性解析方法は, 有効電力出力を行う電力変換装置にも適 用可能である。電力变換装置 1 は自励式 SVC を想定して, 装置の定格電流以下であれば, 電力変換装置 1 連系点の電 圧にかかわらず出力指令值どおりの電力を出力する夕イプ の電力変換装置とし, 定格容量を $50 \mathrm{MVA}$ とする。電力変 換装置 2 は TCT（Thyristor Controlled Transformer）方式 の他励式 SVC とし，定格容量を $35 \mathrm{MVA}$ とする。

また，本論文では，説明を簡略にするため，図 1 のように

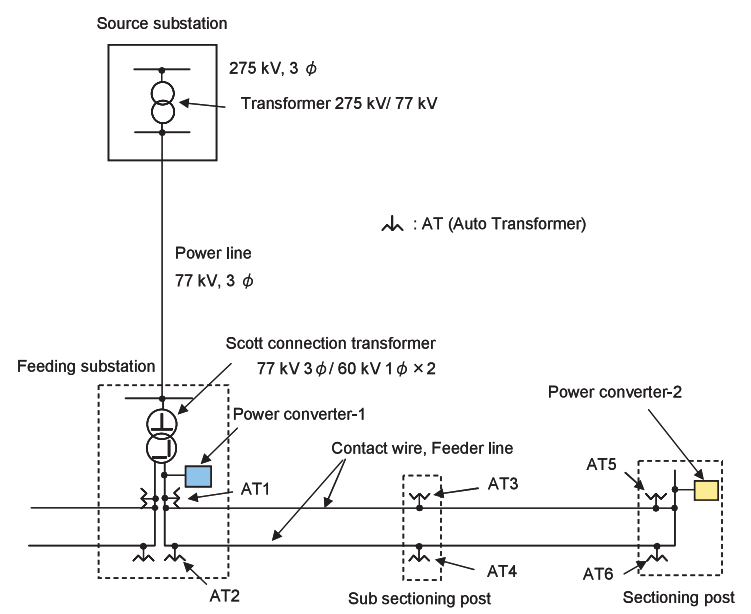

図 1 き電システムの電力系統図

Fig. 1. Power diagram of the feeding system.

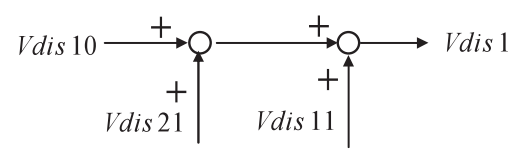

図 2 電圧変化のブロック線図

Fig. 2. Block diagram of voltage fluctuation.

2 組の電力変換装置を含むき電システムをモデルケースと するが, 本論文で述べる安定性解析方法は任意の複数の電力 変換装置を含むき電システムに拡張することが可能である。

$\langle\mathbf{3} \cdot \mathbf{2}\rangle$ 電力変換装置連系点の電圧外乱 き電システム を電力変換装置連系点の電圧変化に着目してブロック線図 化する。電力変換装置連系点の電圧変化の要因となるもの には, 列車負荷変化とそれぞれの電力変換装置の出力とが ある。電力変換装置 1 連系点では, 列車負荷変化に起因す る電圧外乱 Vdis 10 , 電力変換装置 1 自身の出力による電圧 変化 Vdis 11 , 電力変換装置 2 の出力による電圧変化 Vdis 21 の 3 種類の電圧変化が加算されることとなる。電力変換装 置 1 の連系点において検出される電圧変化 Vdis 1 をブロッ ク線図で表すと図 2 のようになる。同様に, 電力変換装置 2 の連系点において検出される電圧変化 Vdis2 は, 列車負 荷変化に起因する電圧外乱 Vdis 20 , 電力変換装置 2 自身の 出力による電圧変化 Vdis 22 , 電力変換装置 1 の出力による 電圧変化 Vdis 12 の 3 種類の電圧変化の和となる。

$\langle\mathbf{3} \cdot \mathbf{3}\rangle$ 電力変換装置の交流電圧制御 電力変換装置連 系点において計測された電圧は, 電圧指令值との差分をと り, 定格電圧で正規化されたうえで電力変換装置の交流電圧 制御回路に入力される。ここで, 電力変換装置 1 及び 2 の 交流電圧制御回路の伝達関数をそれぞれ $G c 1, G c 2$ とする。 交流電圧制御回路は電力变換装置の出力指令值を演算する。

$\langle\mathbf{3} \cdot \mathbf{4}\rangle$ き電電圧応答 交流電圧制御回路の演算結果で ある出力指令值に基づき電力変換装置が出力を行い, 電力 変換装置の出力がそれぞれの電力変換装置の連系点電圧に 変化を与える。ここで, 電力変換装置 1 の出力指令值 Qref 1 に対する電力変換装置 1 及び 2 の連系点の電圧変化の動特 


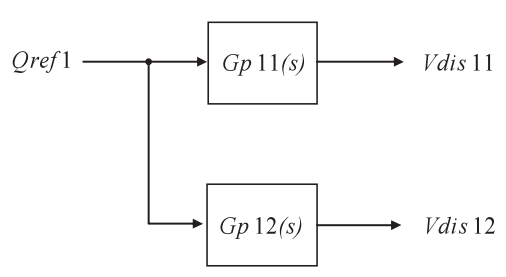

図 3 出力指令值からのき電電圧変化までの ブロック線図

Fig. 3. Block diagram from output reference to feeding voltage fluctuation.

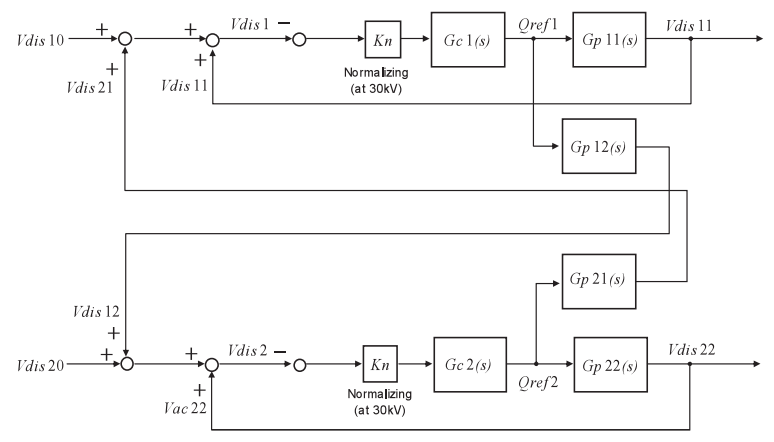

図 42 組の電力変換装置を用いたき電システム のブロック線図

Fig. 4. Block diagram of feeding system with two power converters.

性を表す伝達関数を，それぞれ $G p 11, G p 12$ とする。電力 変換装置 1 の出力指令值 Qref 1 加電力変換装置 1 自身の 出力による電圧変化 Vdis 11 に至るブロック線図を図 3 に 示す。同様に, 電力変換装置 2 の出力指令值 Qref 2 に対す る電力変換装置 1 及び 2 の連系点のき電電圧変化の動特性 を表す伝達関数を，それぞれ $G p 21 ， G p 21$ とする。

$\langle\mathbf{3 . 5}\rangle$ き電システムのブロック線図図 2 の電力変 換装置連系点に扔ける電圧変化のブロック線図, 電力変換 装置の交流電圧制御部分のブロック線図, 図 3 の出力指令 值からき電電圧変化までのブロック線図から，き電システ ム全体のブロック線図を作成すると, 眓 4 のようになる。

\section{4. き電システムの線形回路モデル化}

$\langle\mathbf{4} \cdot \mathbf{1}\rangle$ 電力变換装置出力に対するき電電圧応答の関数 近似図 4 のき電システムのブロック線図のうち伝達関 数を求められていないのは, 電力変換装置の出力指令值に 対するき電電圧変化の動特性を表す伝達関数の $G p$ である。 この伝達関数 $G p$ を求めるために, 電力変換装置の出力を ステップ入力のかたちでき電回路に加え，これに対するき 電電圧応答を比較的低次の線形伝達特性で近似することを 考える。ここでは，経験的に実用上十分な正確さを持つ低 次近似として 2 次遅れシステムで近似することとし，その 妥当性については後にEMTP との比較検証により確認する こととする。

また，実際のき電システムに電力変換装置出力のステッ プ入力を与え，き電電圧応答を実測することも考えることが

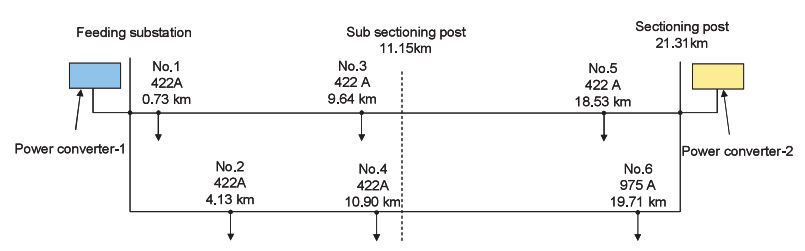

図 5 列車負荷の設定条件

Fig. 5. Position of train load.

できるが, 電力変換装置の交流電圧制御の制御器設計の適否 が問われるのは列車負荷が大きいときの安定性であり, 列車 負荷が大きいときの電力変換装置出力のステップ入力に対 するき電電圧応答の実測を行うことは現実的ではないため, この部分だけは EMTPによる解析で求めることとする。

電力変換装置出力のステップ入力に対するき電電圧応答 を EMTPにより解析する例を示すための列車負荷条件を 図 5 に示す。図 5 の列車負荷条件は, 図 1 のき電システム において想定し得る最も厳しい負荷条件の一つとして設定 する。また, 図 5 中の距離は, き電用変電所からの距離を 示す。また, 図 5 中の電流值は負荷点のき電電圧が $25 \mathrm{kV}$ のときの值を示して抢り, 列車負荷は定電力特性, 負荷力 率はいずれも 1 とする。なお, EMTPでのシミュレーショ ン上の負荷起動時間は，図 5 において,

No.1: $0.2 \mathrm{~s} \rightarrow 0.35 \mathrm{~s} \quad$ No.2: $0.4 \mathrm{~s} \rightarrow 0.55 \mathrm{~s}$

No.3: $0.6 \mathrm{~s} \rightarrow 0.75 \mathrm{~s} \quad$ No.4: $0.8 \mathrm{~s} \rightarrow 0.95 \mathrm{~s}$

No.5: $1.0 \mathrm{~s} \rightarrow 1.15 \mathrm{~s} \quad$ No.6: $9.0 \mathrm{~s} \rightarrow 10.0 \mathrm{~s}$

とする。矢印の左側が負荷の起動時間を, 右側が負荷の起 動完了時間を指し，負荷はこの時間内で $0 \mathrm{~A}$ から図 3 で設 定した負荷条件までランプ関数状に増加させることとする。

ここで, 図 4 の伝達関数 $G p 11, G p 12, G p 21, G p 22$ を 求めるため, 電力変換装置 1 及び 2 に無効電力のステップ 入力を与え, それぞれの場合に打いて電力変換装置 1 連系 点と電力変換装置 2 連系点のき電電圧応答を計算する。

また, 負荷の有効電力と負荷点電圧の関係を示す PV カー ブの一般的な形状では, 負荷の有効電力が大きいほど PV カーブの傾きが大きくなることから,き電電圧応答はき電電 圧範囲によって異なってくるといえる。電力系統の負荷の 有効電力が大きくき電電圧が低いほど, き電電圧応答は大き くなると考えられる。このため, 電力変換装置によりき電電 圧を制御した後のき電電圧を無負荷時の定格電圧の $30 \mathrm{kV}$ より $4 \mathrm{kV}$ 低い $26 \mathrm{kV}$ 以上とすることを想定し， $26.0 \mathrm{kV}$ $26.5 \mathrm{kV}$ の範囲でのき電電圧応答特性を求めることとする。 き電電圧の高い領域はき電電圧の感度は小さくなるため, 上記の範囲より高い電圧領域では, 電力補償装置をより安 定に動作させることができると考えられる。したがって， $26.0 \mathrm{kV} \sim 26.5 \mathrm{kV}$ の範囲でき電電圧応答を求め, これをも とに電力変換装置の電圧制御の安定性を解析することは, 厳 しい条件下での解析を行うことになるということができる。 まず，図 5 に示す列車負荷を全て起動させた状態で，電 力变換装置 1 連系点及び電力変換装置 2 連系点の電圧が約 


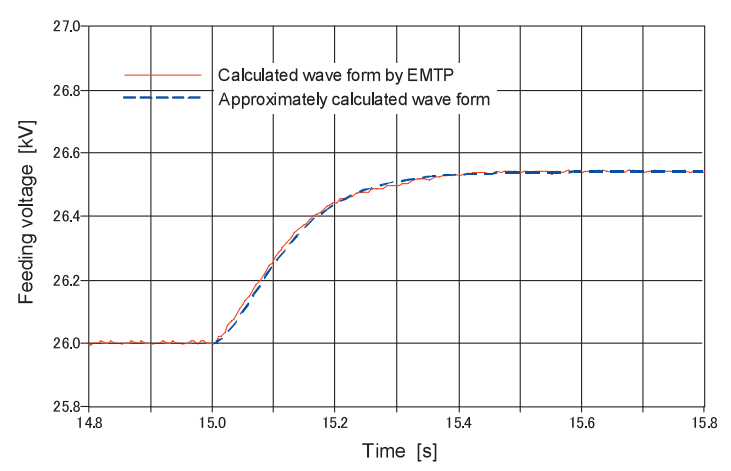

図 6 き電電圧応答波形

Fig. 6. Step response of the feeding voltage.

$26.0 \mathrm{kV}$ となるような電力変換装置 1 及び 2 の無効電力出 力を EMTPにより求める。ここでは，それぞれの電力変換 装置の交流電圧制御を無効とし，無効電力出力を固定值と して, それぞれの電力変換装置連系点電圧が約 $26.0 \mathrm{kV}$ とな るような前記固定值を探索する。EMTPによる計算の結果, 電力変換装置 1 の出力が $0.387 \mathrm{pu}$, 電力変換装置 2 の出力か $0.48 \mathrm{pu}$ でそれぞれの連系点の電圧が約 $26.0 \mathrm{kV}$ となった。 次に，それぞれの電力補償装置の連系点電圧が $26.5 \mathrm{kV}$ となるような無効電力を EMTP の計算により求める。計算

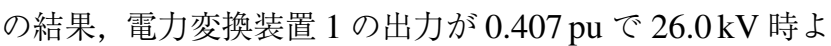
$り+0.020 \mathrm{pu}$, 電力変換装置 2 の出力が $0.508 \mathrm{pu}$ で $+0.028 \mathrm{pu}$ となった。

そこで, 列車負荷を全部起動させ, 電力変換装置 1 の出 力を $0.387 \mathrm{pu}$ に，電力变換装置 2 の出力を $0.48 \mathrm{pu}$ に固定 した状態から，上記で求めた電力変換装置の出力差を，そ れぞれの電力変換装置にステップ的に与え，このときの電 力变換装置連系点電圧の変化を EMTPにより計算する。

き電電圧応答の解析結果例として, 電力变換装置 1 の出 力を $0.387 \mathrm{pu}$ に, 電力変換装置 2 の出力を $0.48 \mathrm{pu}$ に固定し た状態で, 図 5 の列車負荷を全て起動させ, 定常状態となっ た後, 電力変換装置 1 に+0.020 pu の無効電力ステップ入力 を与えたときの電力変換装置 1 連系点のき電電圧実効值の 応答波形を図 6 に示す。なお, 無効電力ステップ入力はシ ミュレーション時間上の時刻 $15.0 \mathrm{~s}$ において与えている。

ここで, EMTPによる計算で得られたき電電圧応答波形 を 2 次遅れシステムで近似する。それぞれのき電電圧応答 波形のオーバーシュート，電圧変化幅，行き過ぎ時間また は整定時間から, ゲイン $K v$, 減衰係数 $\zeta$, 固有角周波数 $\omega_{n}$ を求める。図 6 のき電電圧の応答波形からは, ゲイン $K v=$ 27200 , 減衰係数 $\zeta=0.99$, 固有角周波数 $\omega_{n}=15$ と算定で き，伝達関数 Gp11 は (1) 式で表すことができる。(1) 式の 伝達関数から計算されるステップ応答波形を図 6 に点線で 重ねて示す。

$$
G p 11=\frac{27200 \cdot 15^{2}}{s^{2}+2 \cdot 0.99 \cdot 15 s+15^{2}}
$$

同様にして, 電力変換装置 1 に $+0.020 \mathrm{pu}$ の無効電力ス テップ入力を与えたときの電力変換装置 2 連系点のき電電

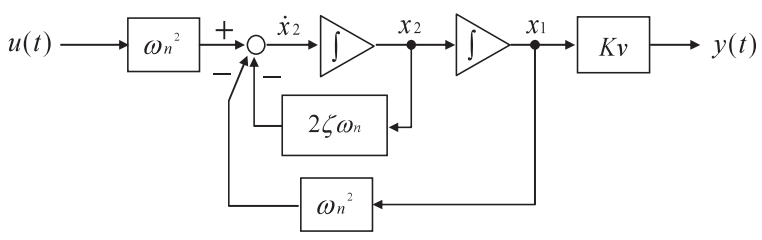

図 7 き電電圧応答の線形回路モデル

Fig. 7. The linearized circuit model of the feeding voltage response.

圧応答波形から $G p 12$ を, 電力変換装置 2 に $+0.028 \mathrm{pu}$ の 無効電力ステップ入力を与えたときの電力変換装置 1 連系 点及び電力変換装置 2 連系点のき電電圧応答波形からそれ ぞれ $G p 21$ 及び $G p 22$ を算定する。

〈4・2〉き電電圧応答部分の線形回路モデル まず，2 次遅れシステムで近似した電力変換装置の出力に対するき 電電圧応答部分を線形回路モデル化する。

き電電圧応答特性の伝達関数 $G p(s)$ は以下の (2) 式で表 される。ここで, $Y(s)$ は出力, つまり, き電電圧応答を表 し, $U(s)$ はき電電圧応答特性への入力, つまり, 電力変換 装置の出力を表す。

$$
G p(s)=\frac{Y(s)}{U(s)}=\frac{K v \cdot \omega_{n}{ }^{2}}{s^{2}+2 \zeta \omega_{n} \cdot s+\omega_{n}{ }^{2}}
$$

これを変形して，

$$
\frac{Y(s)}{X(s)} \cdot \frac{X(s)}{U(s)}=K v \cdot \frac{\omega_{n}^{2}}{s^{2}+2 \zeta \omega_{n} \cdot s+\omega_{n}^{2}}
$$

(3) 式より,

$$
\begin{aligned}
& \left(s^{2}+2 \zeta \omega_{n} \cdot s+\omega_{n}{ }^{2}\right) X(s)=\omega_{n}{ }^{2} \cdot U(s) \\
& \ddot{x}(t)+2 \zeta \omega_{n} \cdot \dot{x}(t)+\omega_{n}{ }^{2} \cdot x(t)=\omega_{n}{ }^{2} \cdot u(t)
\end{aligned}
$$

ここで， $x(t)=x_{1}, \dot{x}(t)=x_{2}$ とすると, 状態方程式 (4) を導くことができる。

$$
\dot{x}_{2}=-\omega_{n}^{2} \cdot x_{1}-2 \zeta \omega_{n} \cdot x_{2}+\omega_{n}^{2} \cdot u(t)
$$

また，同じく (3) 式より，出力方程式 (5) を導くことがで きる。

$$
\begin{aligned}
& Y(s)=K v \cdot X(s) \\
& y(t)=K v \cdot x_{1} \cdots
\end{aligned}
$$

以上より，(4) 式の状態方程式及び (5) 式の出力方程式か らを 2 次遅れシステムで近似した電力変換装置の出力に対 するき電電圧応答部分を線形回路モデル化すると，図 7 の ようになる。

$\langle\mathbf{4} \cdot \mathbf{3}\rangle$ 交流電圧制御部分の線形回路モデル 交流電 圧制御はその制御方法から具体的な伝達関数として求める ことができる。例えば，ここでは電力変換装置 1 の交流電 圧制御を比例 +1 次遅れ制御, 電力变換装置 2 の交流電圧 制御を 1 次遅れ制御とすると, 電力変換装置 1 の交流電圧 制御の伝達関数 $G c 1$ は (6) 式, 電力変換装置 2 の交流電圧 


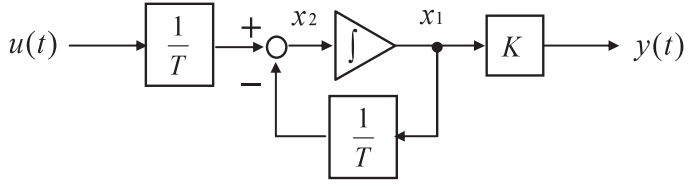

困 81 次遅れ制御の線形回路モデル

Fig. 8. The linearized circuit model of the first order control.

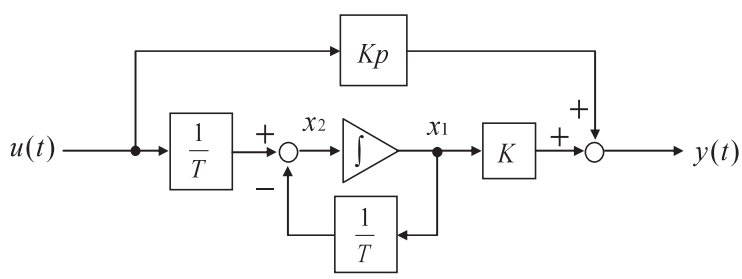

図 9 比例 +1 次遅れ制御の線形回路モデル

Fig. 9. The linearized circuit model of the proportional control and the first order control.

制御の伝達関数 $G c 2$ は (7) 式で表すことができる。

$$
\begin{aligned}
G c 1 & =K p_{1}+\frac{K_{1}}{1+T_{1} s} \\
G c 2 & =\frac{K_{2}}{1+T_{2} s} \cdots \cdots
\end{aligned}
$$

ここで， $K p_{1}$ は比例ゲインを， $K_{1}$ 及び $T_{1}$ はそれぞれ電力 変換装置 1 の交流電圧制御の 1 次遅れゲイン及び 1 次遅れ 時定数を， $K_{2}$ 及び $T_{2}$ はそれぞれ電力変換装置 2 の交流電 圧制御の 1 次遅れゲイン及び 1 次遅れ時定数を表す。

1 次遅れ制御部分の線形回路モデルは以下のように作成 する。1 次遅れ制御への入力を $U(s)$, 出力を $Y(s)$ とすると 以下の関係が成り立つ。

$$
\frac{Y(s)}{U(s)}=\frac{K}{1+T s}
$$

これを変形して，

$$
\frac{Y(s)}{X(s)} \cdot \frac{X(s)}{U(s)}=K \cdot \frac{1}{1+T s}
$$

(8) 式より,

$$
\begin{aligned}
& (1+T s) X(s)=U(s) \\
& T \cdot \dot{x}(t)+x(t)=u(t)
\end{aligned}
$$

ここで, $x(t)=x_{1}, \dot{x}(t)=x_{2}$ とすると, 状態方程式 (9) を導くことができる。

$$
x_{2}=-\frac{1}{T} x_{1}+\frac{1}{T} u(t)
$$

また, 同じく(8) 式より, 以下の出力方程式 (10) を導く ことができる。

$$
\begin{aligned}
& Y(s)=K \cdot X(s) \\
& y(t)=K \cdot x_{1} \cdots
\end{aligned}
$$

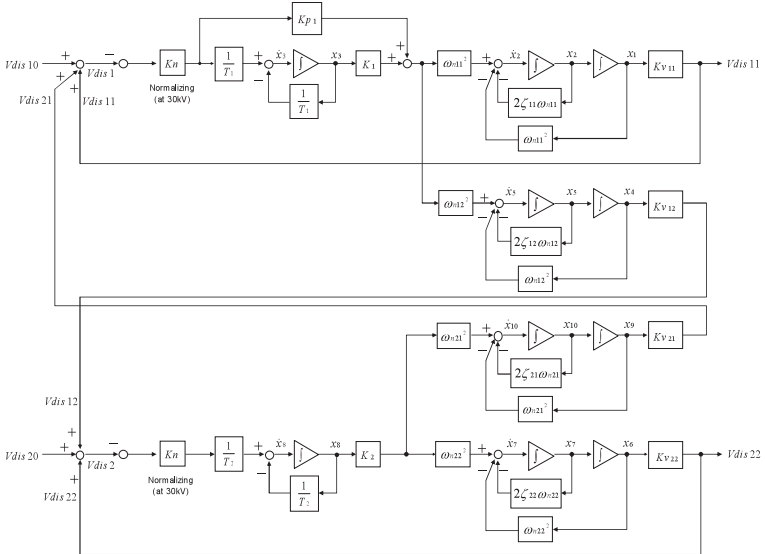

図 102 組の電力変換装置を用いたき電システム の線形回路モデル

Fig. 10. The linearized circuit model of the feeding system with two power converters.

以上より，(9) 式の状態方程式及び (10) 式の出力方程式 から 1 次遅れ制御部分を線形回路モデル化すると, 図 8 の ようになる。

また，比例 +1 次遅れ制御は，1 次遅れ制御に単に比例 制御を加算したものであるから，これを線形回路モデルに すると図 9 のようになる。

〈4・4〉き電システム全体の線形回路モデル 図 4 に示 すような 2 組の電力変換装置を持つき電システムのブロッ ク線図と, 図 7 に示すようなき電電圧応答部分の線形回路 モデルと, 図 8 及び図 9 に示す交流電圧制御部分の線形回 路モデルから，2 組の電力変換装置を用いたき電システム 全体の線形回路モデルは図 10 のように示すことができる。

\section{5. き電システムの状態方程式と極の算出}

$\langle\mathbf{5} \cdot \mathbf{1}\rangle$ 線形回路モデルの状態変数に関する連立 1 次方 程式図 10 に示すき電システムの線形回路モデルから, 各状態変数に関する連立 1 次方程式を求める。状態変数 $x_{1}$ は状態変数 $x_{2}$ の積分に等しいので, $x_{1}$ の微分を $\dot{x}_{1}$ で表す と, 以下の (11) 式が成り立つ。

$$
\dot{x}_{1}=x_{2}
$$

次に， $x_{2}$ の微分である $\dot{x}_{2}$ は, 図 10 の線形回路モデルの 加算器や乗算器の関係から，次のように表すことができる。

$$
\begin{aligned}
\dot{x}_{2}= & -\omega_{n 11}^{2} \cdot x_{1}-2 \zeta_{11} \omega_{n 11} \cdot x_{2}+\omega_{n 11}^{2} K_{1} \cdot x_{3} \\
& -\omega_{n 11}^{2} K p_{1} K n \cdot V d i s 1
\end{aligned}
$$

ここでVdis 1 は電力変換装置 1 連系点における電圧外乱 の和なので，

$$
\begin{aligned}
V d i s 1 & =V d i s 11+V d i s 21+V d i s 10 \\
& =K v_{11} \cdot x_{1}+K v_{21} \cdot x_{9}+V d i s 10
\end{aligned}
$$

となり，したがって $\dot{x}_{2}$ は以下の (12) 式のように表すこと ができる。 


$$
\begin{aligned}
\dot{x}_{2}= & -\omega_{n 11}^{2} \cdot x_{1}-2 \zeta_{11} \omega_{n 11} \cdot x_{2}+\omega_{n 11}^{2} K_{1} \cdot x_{3} \\
& -\omega_{n 11}^{2} K p_{1} K n \cdot\left(K v_{11} \cdot x_{1}+K v_{21} \cdot x_{9}+\text { Vdis } 10\right)
\end{aligned}
$$

同様にして, 残りの状態变数は, 以下の $(13) \sim(20)$ 式の ように表すことができる。

$$
\begin{aligned}
& \dot{x}_{3}=-\frac{1}{T_{1}} \cdot x_{3}-\frac{K n}{T_{1}} \cdot\left(K v_{11} \cdot x_{1}+K v_{21} \cdot x_{9}+\operatorname{Vdis} 10\right) \\
& \dot{x}_{4}=x_{5} \ldots \ldots \ldots \ldots \ldots \ldots \ldots \ldots \ldots \ldots \ldots \ldots \ldots \ldots \ldots \ldots \\
& \dot{x}_{5}=\omega_{n 12}^{2} K_{1} \cdot x_{3}-\omega_{n 12}^{2} \cdot x_{4}-2 \zeta_{12} \omega_{n 12} \cdot x_{5} \\
& -\omega_{n 12}^{2} K p_{1} K n \cdot\left(K v_{11} \cdot x_{1}+K v_{21} \cdot x_{9}+V d i s 10\right) \\
& \text {................ (15) } \\
& \dot{x}_{6}=x_{7} \\
& \dot{x}_{7}=-\omega_{n 22}^{2} \cdot x_{6}-2 \zeta_{22} \omega_{n 22} \cdot x_{7}+\omega_{n 22}^{2} K_{2} \cdot x_{8} \\
& \dot{x}_{8}=-\frac{1}{T_{2}} \cdot x_{8}-\frac{K n}{T_{2}} \cdot\left(K v_{22} \cdot x_{6}+K v_{12} \cdot x_{4}+V d i s 20\right) \\
& \begin{array}{l}
\dot{x}_{9}=x_{10} \ldots \ldots \ldots \ldots \ldots \ldots \ldots \ldots \ldots \ldots \\
\dot{x}_{10}=\omega_{n 21}{ }^{2} K_{2} \cdot x_{8}-\omega_{n 21}{ }^{2} \cdot x_{9}-2 \zeta_{21} \omega_{n 21} \cdot x_{10}
\end{array}
\end{aligned}
$$

〈5・2〉き電システムの状態方程式の算出 き電シス テムの線形回路モデルから算出した連立 1 次方程式をもと に，き電システムの状態方程式を導く。まず，き電システ ムの状態方程式を以下の (21) 式で定義する。

$$
\dot{\mathbf{x}}=\mathbf{A x}+\mathbf{B u}
$$

図 2 より, 列車負荷変化に伴うき電電圧変化を電圧外乱 としてき電システムの入力としていることから，(21) 式の 入力ベクトル $\mathbf{u}$ は以下の (22) 式で表される 2 行 1 列の行 列となる。

$$
\mathbf{u}=\left[\begin{array}{l}
V \text { dis } 10 \\
V \text { dis } 20
\end{array}\right]
$$

$$
\mathbf{A}=\left[\begin{array}{ccccc}
0 & 1 & 0 & 0 & 0 \\
-\omega_{n 11}{ }^{2}\left(1+K p_{1} K n K v_{11}\right) & -2 \zeta_{11} \omega_{n 11} & \omega_{n 11}^{2} K_{1} & 0 & 0 \\
-\frac{K n K v_{11}}{T_{1}} & 0 & -\frac{1}{T_{1}} & 0 & 0 \\
0 & 0 & 0 & 0 & 1 \\
-\omega_{n 12}{ }^{2} K p_{1} K n K v_{11} & 0 & \omega_{n 12}^{2} K_{1} & -\omega_{n 12}^{2} & -2 \zeta_{12} \omega_{n 12} \\
0 & 0 & 0 & 0 & 0 \\
0 & 0 & 0 & 0 & 0 \\
0 & 0 & 0 & -\frac{K n K v_{12}}{T_{2}} & 0 \\
0 & 0 & 0 & 0 & 0 \\
0 & 0 & 0 & 0 & 0
\end{array}\right.
$$

したがって, (11)〜(20) 式の 10 元連立 1 次方程式より, (21) 式の入力行列 $\mathbf{B}$ は以下の (23) 式で表される 10 行 2 列 の行列として算定される。

$$
\mathbf{B}=\left[\begin{array}{cc}
0 & 0 \\
-\omega_{n 11}{ }^{2} K p_{1} K n & 0 \\
-\frac{K n}{T_{1}} & 0 \\
0 & 0 \\
-\omega_{n 12}{ }^{2} K p_{1} K n & 0 \\
0 & 0 \\
0 & 0 \\
0 & -\frac{K n}{T_{2}} \\
0 & 0 \\
0 & 0
\end{array}\right]
$$

また, (11) (20) 式の状態変数の 10 元連立 1 次方程式よ り, (21) 式のシステム行列 $\mathbf{A}$ は (24) 式で表される 10 行 10 列の行列として算定される。

(22), (23), (24) 式より, き電システムの状態方程式 (21) が算定されることとなる。

次に, き電システムの出力方程式を算定する。き電シス テムの出力方程式を (25) 式のとおり定義する。

$$
\mathbf{y}=\mathbf{C x}+\mathbf{D u}
$$

き電システムの出力を各電力変換装置連系点における電 圧変化の和とすると, (25) 式の出力行列 $\mathbf{y}$ は以下の (26) 式 で表すことができる。

$$
\mathbf{y}=\left[\begin{array}{l}
V d i s 1 \\
V d i s 2
\end{array}\right]
$$

一方, 図 10 より, Vdis1, Vdis2 と各状態変数との間に は以下の関係が成り立つ。

$$
\begin{aligned}
& V d i s 1=K v_{11} \cdot x_{1}+K v_{21} \cdot x_{9}+V d i s 10 \\
& V d i s 2=K v_{22} \cdot x_{6}+K v_{12} \cdot x_{4}+V d i s 20
\end{aligned}
$$

入力行列 $\mathbf{u}$ は (22) 式で表されるため, (25) 式の行列 $\mathbf{C}$ 及びDは以下のように算定することができる。

$\left.\begin{array}{ccccc}0 & 0 & 0 & 0 & 0 \\ 0 & 0 & 0 & -\omega_{n 11}{ }^{2} K p_{1} K n K v_{21} & 0 \\ 0 & 0 & 0 & -\frac{K n K v_{21}}{T_{1}} & 0 \\ 0 & 0 & 0 & 0 & 0 \\ 0 & 0 & 0 & -\omega_{n 12}{ }^{2} K p_{1} K n K v_{21} & 0 \\ 0 & 1 & 0 & 0 & 0 \\ -\omega_{n 22}^{2} & -2 \zeta_{22} \omega_{n 22} & \omega_{n 22}^{2} K_{2} & 0 & 0 \\ -\frac{K n K v_{22}}{T_{2}} & 0 & -\frac{1}{T_{2}} & 0 & 0 \\ 0 & 0 & 0 & 0 & 1 \\ 0 & 0 & \omega_{n 21}{ }^{2} K_{2} & -\omega_{n 21}^{2} & -2 \zeta_{21} \omega_{n 21}\end{array}\right]$




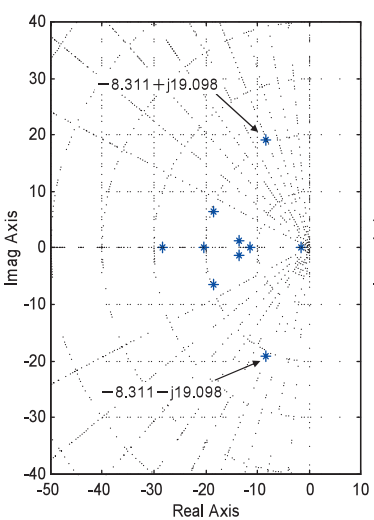

(a) $K p=2$

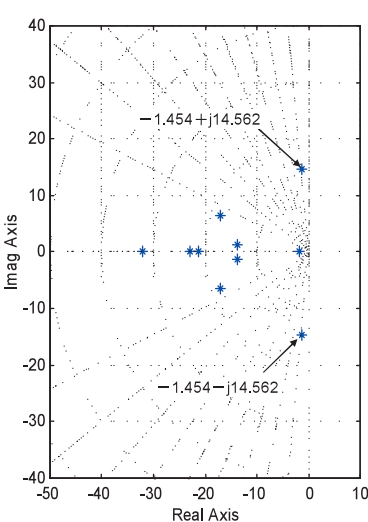

(b) $K p=0$
図 11 き電システムの極の算出結果

Fig. 11. The calculated pole assignment of the feeding system.

$$
\begin{aligned}
\mathbf{C} & =\left[\begin{array}{cccccccccc}
K v_{11} & 0 & 0 & 0 & 0 & 0 & 0 & 0 & K v_{21} & 0 \\
0 & 0 & 0 & K v_{12} & 0 & K v_{22} & 0 & 0 & 0 & 0
\end{array}\right] \\
\mathbf{D} & =\left[\begin{array}{ll}
1 & 0 \\
0 & 1
\end{array}\right] \ldots \ldots \ldots \ldots \ldots \ldots \ldots \ldots \ldots \ldots \ldots \ldots \ldots \ldots \ldots \ldots \ldots \ldots
\end{aligned}
$$

以上の上うに, 列車負荷変化に伴うき電電圧変化, 各電 力変換装置の交流電圧制御の伝達関数, 電力変換装置の出 力に対するき電電圧応答の伝達関数を特定することにより, 複数の電力変換装置を含むき電システム全体の状態方程式 及び出力方程式を導き出すことができる。

$\langle\mathbf{5} \cdot \mathbf{3}\rangle$ き電システムの極配置の算出き電システム の状態方程式 (21) を算定することができたので，これをも とにき電システムの極配置を算出していく。き電システム の極は, 状態方程式 (21) のシステム行列 $\mathbf{A}$ の固有值とし て求めることができる。つまり, 各電力変換装置の交流電 圧制御の各制御定数と, 電力変換装置の出力に対する各電 力変換装置連系点のき電電圧応答の 2 次遅れシステムによ る近似が求まっていれば，き電システムの極配置を算出で きることとなる。

電力変換装置 1 及び電力変換装置 2 の交流電圧制御の制 御定数をパラメータとして, 図 1 のき電システムの極配置 を算出した結果を図 11 に示す。なお，図 11 中の虚軸との 角度の補助線は, 二次系の減衰係数 0.1 毎に引いている。

減衰係数 すると，(31)式のように表すことができる。

$$
\zeta=\frac{-\operatorname{Re}(p)}{\sqrt{\operatorname{Re}(p)^{2}+\operatorname{Im}(p)^{2}}}
$$

したがって，極の実数部が正の值であると，減衰係数は 負の值となり, き電システムは安定しない。また, 減衰係 数が大きいほど過渡的な振動が小さくなり, き電システム はより安定であるといえる。以上より，き電システムが安 定であるためには，減衰係数が正，つまり極の実数部が負 の值であることが絶対的な条件で, 減衰係数ができるだけ
大きくなるほうが望ましいということになる。この考え方 をもとに, き電システムの安定性判定と電力変換装置の交 流電圧制御の制御器設計の評価を行うこととする。

図 11 の (a) は電力変換装置 1 の交流電圧制御をスロープ 特性を持つ比例積分制御とし, その比例ゲインを $K p=2$, 積分ゲインを $K i=20$, スロープリアクタンスを $X s l=0.05$ とし, また, 電力変換装置 2 の交流電圧制御を 1 次遅机制 御とし, そのゲインを $K_{2}=10$, 時定数を $T_{2}=1$ としたと きの極配置算出結果である。ここで, スロープリアクタン スとは, 電力変換装置の出力に乗算し, その演算結果を電 圧指令值から減算するための設定值を指している。つまり, 比例積分制御が目指す電圧目標值は固定ではなく, 電力変 換装置の出力に対し $-X s l$ の傾きを持つスロープ特性とな る。図 11 の (b) は, 電力変換装置 1 の交流電圧制御の制御 定数のうち, 比例ゲインを $K p=0$ とし, その他の制御定数 及び電力変換装置 2 の交流電圧制御の制御定数は図 11(a) の場合と同じとしたときの極配置算出結果である。なお， スロープ特性を持つ比例積分制御は, 比例 +1 次遅れ制御 のかたちに変形することができ, 図 9 の線形回路モデルが 適用できる。

図 11(a)の算出例では, 減衰倸数が最も小さいものでも 約 0.4 あり，安定なシステムであることがわかる。これに 対し, 図 11(b) の算出例のように電力変換装置 1 の比例制 御要素がないと, 減衰係数の最小值が約 0.1 と顕著に小さ くなる。これより, このき電システムの場合は, 電力変換 装置 1 の交流電圧制御に比例制御要素を入れたほうがき電 電圧は安定であるということがわかる。

このように, 各電力変換装置の交流電圧制御の制御定数 をパラメータとしてき電システムの極を算出することがで きるため, EMTPによる解析より短時間で, かつ, 体系的 にき電システムの安定性を解析することができる。

\section{6. 線形回路モデルの EMTP による妥当性検証}

き電システムの線形回路モデルや電力変換装置の出力に 対するき電電圧応答を 2 次遅れシステムで近似することの 妥当性を検証するために, EMTPによる列車負荷起動に伴 う過渡現象の計算結果との比較を行う。

電力系統条件及び負荷条件は図 1 及び図 5 の条件と同じ とする。また, 電力変換装置 1 の電圧指令值はトロリ線一き 電線間で $53 \mathrm{kV}$ (トロリ線ーレール間 $26.5 \mathrm{kV})$, 電力変換装 置 2 の電圧指令值はトロリ線ーレール間で $25.5 \mathrm{kV}$ として, き電電圧応答特性を求めたき電電圧範囲に相当する電圧範 囲となるように設定した。

EMTP によるき電電圧の計算結果を図 12 に示す。 図 12(a) は, 電力変換装置 1 及び 2 の交流電圧制御の制 御定数を図 11(a) の極配置算出条件と同じとしたときの計 算結果を示し, 図 12(b) は図 11(b) の極配置算出条件と同 じとしたときの計算結果を示している。

図 12(a)では, 全列車負荷起動後も安定してき電電圧が 制御されて㧍り，図 11(a)のき電システムの極算出結果が 


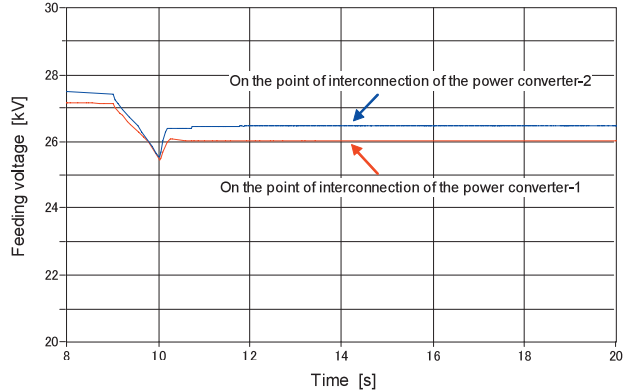

(a) $K p=2$

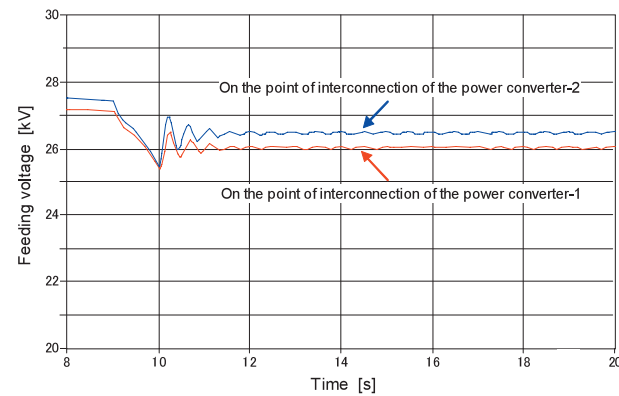

(b) $K p=0$

図 12 EMTPによるき電電圧計算結果

Fig. 12. The calculated result of the feeding voltage by EMTP.

妥当であることがわかる。

図 12(b) では，全列車負荷起動後のき電電圧に振動が見 られ，その後の安定度も悪い。図11(b)に示したように，減 衰係数の小さい極があることと EMTP の計算結果が概ね一 致していると言える。

以上より，図 10 のようにき電システムを線形回路モデ ル化すること，及び，電力変換装置の出力に対するき電電 圧応答を 2 次遅れシステムで近似することは妥当であると いうことができる。

\section{7. まとめ}

交流電圧制御を行う複数の電力変換装置を用いたき電シ ステムについて，非線形性も考慮した精細な数值解析を行 うことのできるEMTPによる解析と比較して簡易で体系的 なき電システムの制御系の設計に資する新しい安定性解析 方法を以下のとおり確立した。

（1）EMTP で計算した電力変換装置の出力に対するき 電電圧応答を 2 次遅れシステムで近似し, き電システム全 体のブロック線図と伝達関数を算定した。

（2）き電システムのブロック線図と伝達関数をもとに き電システムの線形回路モデルを作成した。

（3）き電システムの線形回路モデルから，き電システ ムの状態方程式及び出力方程式を算出した。この状態方程 式からき電システムの極配置の算出も可能となった。

また，EMTPにより，き電システムの線形回路モデル及 び極配置算出結果が妥当であることを示した。

き電システムの線形回路モデルを構築したことにより，
EMTPにより解析する場合と比較して短時間でのき電電圧 の解析が可能となり，交流電圧制御の制御器設計を短期間 で完成させるための有効な手段となった。さらに, 極配置 の算出を行えることにより，設計した制御器が，き電電圧 を安定に制御するためにどれだけの余裕を持てているかを 定量化することができ，体系的な制御器設計を行うことが 可能となった。

この安定性解析方法は，沼津周波数変換変電所に新設し た固定力率出力方式の交流電圧制御を行う静止形周波数変 換装置 ${ }^{(1)}$ や栗東変電所に新設したき電側電力融通方式電力 補償装置（RPC：Railway static Power Conditioner）の交流 電圧制御の制御器の体系的設計に有用であった。その設計 に基づく実装置は，2009年 2 月より，順調に運転している。

(平成 21 年 7 月 13 日受付，平成 21 年 11 月 5 日再受付)

\section{文献}

(1) K. Kunomura, M. Onishi, M. Kai, N. Iio, M. Otsuki, and T. Ishizuka: "Electronic Frequency Converter Controls A.C. Voltage Using Fixed Power Factor Method", IEEJ Trans. IA, Vol.129, No.7, pp.768-774 (2009-7) (in Japanese)

久野村健 · 大西 満 - 甲斐正彦・飯尾尚隆・大槻みどり・石塚智嗣： 「固定力率出力方式の交流電圧制御を行う静止形周波数変換装置」, 電学論 D, 129, 7, pp.768-774 (2009-7)

(2) K. Ito, N. Nagayama, M. Otsuki, T. Ishizuka, F. Aoyama, T. Yoshino, J. Takazane, M. Oki, and K. Kunomura: "Electronic Frequency Converter", Proc. of the 2004 JIAS Conf., III, pp.347-352 (2004) (in Japanese) 伊藤健治・長山徳幸 ·大槻みどり - 石塚智嗣 - 青山文夫 ·吉野輝雄 · 高實潤史朗 ·大木正之 ·久野村健：「静止形周波数変換装置の開発」, 平 16 産業応用部門大会, III, pp.347-352 (2004)

(3) Y. Shinki, A. Koyama, K. Temma, and N. Morishima : "Study of SVG control under the change of power system configuration", IEEJ, PE-08-172 (2008-12) (in Japanese)

新木依子・児山篤紘・天満耕司・森嶋直樹：「系統構成変更における SVG 制御検討」, 電学電力技術研, PE-08-172 (2008-12)

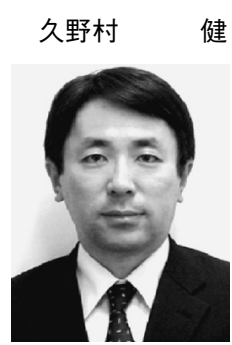

（正員） 1967 年 10 月 23 日生。 1990 年 3 月，東 京大学工学部電気工学科卒業。同年 4 月東海旅客 鉄道（株）入社，現在に至る。主として，東海道 新幹線へのパワーエレクトロニクス機器の導入に 関する研究・計画に従事。

古 関 隆 章 (正員) 1963 年 7 月 29 日生。1992 年, 東京大学

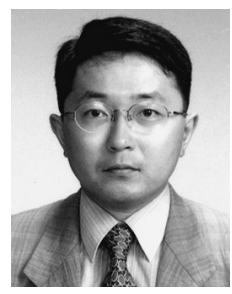
(正員) 1963 年 7 月 29 日生。1992 年, 東京大子 大学院工学系研究科電気工学専攻博士昩柦修了, 博士 (工学)。同年 4 月より東京大学に勤務，現 在東京大学大学院工学系研究科電気系工学専攻准 教授。主として, 電気工学, 制御工学の電気駆動, 産業システム, 交通分野への応用に関する研究に 従事。日本機械学会, 日本精密工学会, 日本 AEM 学会, 日本鉄道電気技術協会, VDI, IEEE の会員。 